\title{
Pengukuran dan Perbaikan Kualitas Pelayanan PT Pos Indonesia Menggunakan Metode Importance Performance Analysis (IPA)
}

\author{
Dani Leonidas Sumarna', Muhammad Faisal ${ }^{2)}$ \\ 1)Program Studi D IV Logistik Bisnis, Politeknik Pos Indonesia \\ danileo@poltekpos.ac.id. \\ 2)Program Studi D IV Logistik Bisnis, Politeknik Pos Indonesia \\ muhamadfaisalx2@gmail.com
}

\begin{abstract}
Abstrak
PT. Pos Indonesia belum menjadi brand atau produk unggulan di mata masyarakat Indonesia. Selama 4 tahun berturut-turut PT. Pos Indonesia menduduki peringkat ketiga dibawah JNE, TIKI bahkan pada tahun 2018, PT Pos Indonesia menduduki peringkat 4 dengan skor top brands Indonesia sebesar $11.60 \%$ dibawah para pesaingnya JNE dengan skor 45\%, J\&T 13.90\%, TIKI 13.60\%. Kualitas pelayanan (Service Quality) dibangun atas adanya perbandingan dua faktor utama yaitu persepsi pelanggan atas layanan yang nyata mereka terima (perceived service) dengan layanan yang sesungguhnya diharapkan.

Penelitian ini menggunakan pendekatan penelitian deskriptif verifikatif dengan pendekatan survey. Data diperoleh dengan menyebarkan kuisioner kepada 150 responden. Penelitian ini menggunakan dimensi servqual dan dilakukan perbaikan menggunakan metode Importance Performance Analysis (IPA). Hasil penelitian didapat bahwa didapat 2 atribut yang ada didalam kuadran A yang merupakan prioritas utama perbaikan yaitu Karyawan pos memberikan solusi apabila terjadi permasalahan kiriman dengan nilai kinerja 3.720, harapan 4.247 dan gap sebesar -0.527 dan Pos bertanggung jawab terhadap keamanan dalam pengiriman barang yang diterima dengan nilai kinerja 3.847, harapan 4.360 dan gap sebesar -0.513. Berdasarkan hasil penelitian, saran yang diberikan adalah memberikan pengarahan kepada para karyawan mengenai pentingnya berinisiatif dalam melayani pelanggan yang membutuhkan bantuan, dapat juga dilakukan penembahan papan informasi untuk dapat mengurangi frekuensi timbulnya pertanyaan dari para pelanggan dan kepercayaan adalah segalanya dalam bisnis jasa, informasikan pada pelanggan yang ingin mengirimkan barang bahwa pos bertanggung jawab atas keamanan dalam pengiriman barang.
\end{abstract}

\section{Kata Kunci: Kualitas Pelayanan, Pos Indonesia, Importance Performance Analysis}

\section{PENDAHULUAN}

Pada hakikatnya setiap industri jasa pengiriman paket memiliki peluang yang sama untuk dipilih jasa pengirimannya, namun demikian dengan melihat beberapa kasus pengaduan PT. Pos Indonesia pada website lapor.go.id dapat merubah tingkat kepercayaan konsumen terhadap kinerja PT. Pos Indonesia. Disamping itu berdasarkan survey yang dilakukan oleh topbrand award jumlah konsumen yang memilih PT. Pos Indonesia hanya $6 \%$ - 11\% dari jumlah pasar yang ada, hal ini dapat mengindikasikan bahwa konsumen PT. Pos Indonesia mulai beralih menggunakan jasa pengiriman lain yang dipercayainya memiliki layanan pengiriman yang lebih

memuaskan. Berikut tabel 1 data top brands untuk kategori jasa kurir:

https://ejurnal.poltekpos.ac.id/index.php/logistik/index
Tabel 1 Top Brands 4 Tahun Terakhir

\begin{tabular}{|c|c|c|c|c|c|c|c|}
\hline \multicolumn{2}{|c|}{2015} & \multicolumn{2}{c|}{2016} & \multicolumn{2}{c|}{2017} & \multicolumn{2}{c|}{2018} \\
\hline Merk & TBI & Merk & TBI & Merk & TBI & Merk & TBI \\
\hline JNE & $43.50 \%$ & JNE & $47.60 \%$ & JNE & $49.40 \%$ & JNE & $45 \%$ \\
\hline TIKI & $36.20 \%$ & TIKI & $35.70 \%$ & TIKI & $34.70 \%$ & J\&T & $13.90 \%$ \\
\hline POS & $6.70 \%$ & POS & $9.60 \%$ & POS & $8.40 \%$ & TIKI & $13.60 \%$ \\
\hline DHL & $2.10 \%$ & DHL & $1.30 \%$ & DHL & $1.30 \%$ & POS & $11.60 \%$ \\
\hline & & & & & & DHL & $3.50 \%$ \\
\hline
\end{tabular}

Sumber: (www.topbrand-award.com), 2019

Berdasarkan tabel 1 dapat disimpulkan bahwa brand PT. Pos Indonesia belum menjadi brand atau produk unggulan di mata masyarakat Indonesia. Selama 4 tahun berturut-

turut PT .Pos Indonesia menduduki peringkat ketiga dibawah JNE, TIKI bahkan pada tahun 2018, PT Pos Indonesia menduduki peringkat 4 dengan skor top brands Indonesia sebesar $11.60 \%$ dibawah para pesaingnya JNE dengan skor $45 \%$, J\&T $13.90 \%$, TIKI $13.60 \%$, kalah dengan pesaing baru yang baru berumur 4 tahun yaitu J\&T. Brand atau merk merupakan hal pertama yang dilihat 
pelanggan ketika ingin membeli atau menggunakan jasa suatu perusahaan. Salah satu faktor yang menentukan keberhasilan suatu perusahaan adalah kemampuan perusahaan memberikan pelayanan yang berkualitas kepada konsumen. Kualitas pelayanan (service quality) dibangun atas adanya perbandingan dua faktor utama yaitu persepsi pelanggan atas layanan yang nyata mereka terima (perceived service) dengan layanan yang sesungguhnya diharapkan. Dengan memberikan kualitas pelayanan yang terbaik kepada pelanggan, ketika pelangganmembutuhkan suatu jasa maka akan terbenak dalam pikirannya suatu brand yang menurut nya merupakan pilihan terbaik didasari atas pengalaman yang dirasakan sebelumnya. Melihat PT. Pos Indonesia selalu berada di posisi ke 3 pada tahun 2015, 2016 dan 2017 serta posisi ke 4 pada tahun 2018, penulis berminat untuk melakukan pengukuran kepuasan pelanggan untuk melihat sejauh mana kualitas pelayanan bukti fisik (tangible), kehandalan (reliability), daya tanggap (responsiveness), jaminan (assurance), empati (empathy). Konsep SERVQUAL atau dimensi kualitas pelayanan tersebut merupakan konsep yang paling banyak digunakan oleh pelaku bisnis diseluruh dunia yang berkecimpung dalam hal pelayanan pelanggan. Hasil dari pengukuran tersebut akan menjadi pertimbangan perbaikan sektor yang di nilai kurang memuaskan oleh pelanggan sehingga diharapkan dapat meningkatkan kualitas pelayanan. Berdasarkan uraian latar belakang diatas, peneliti tertarik untuk melakukan penelitian mengenai “Pengukuran dan Perbaikan Kualitas Pelayanan PT. Pos Indonesia dengan Metode Importance Performance Analysis (IPA)".

\section{METODE PENELITIAN}

Penelitian ini menggunakan pendekatan penelitian deskriptif verifikatif dengan pendekatan survey. Penelitian deskriptif adalah penelitian yang bertujuan untuk menggambarkan atau melakukan keadaan objek atau subjek penelitian. Data yang diperoleh secara langsung dari responden. Data ini diperoleh melalui penyebaran kuisioner, yaitu dengan menyebarkan daftar pertanyaan atau menggunakan google form yang kemudian disebar melalui social media. Dalam penelitian ini data diperoleh langsung dari konsumen yang pernah menggunakan jasa pengiriman PT. Pos Indonesia. Ukuran populasi dalam penelitian sangat banyak dan tidak dapat diketahui dengan pasti, maka besar sampel yang digunakan menurut Rao Purba (2006) dalam Kharis (2011:50) menggunakan rumus sebagai berikut:

$$
\mathrm{n}=\frac{\mathrm{Z}^{2}}{4(\mathrm{Moe})^{2}}
$$

Keterangan:

$\mathrm{n} \quad=$ ukuran sampel
$\mathrm{Z}=1,96$ score pada tingkat signifikansi tertentu (derajat keyakinan 95\%)

Moe = margin of error, tingkat kesalahan maksimum adalah $10 \%$

Dengan menggunakan rumus diatas, maka diperoleh perhitungan sebagai berikut:

$$
\begin{aligned}
& \mathrm{n}=\frac{(1,96)^{2}}{4(10 \%)^{2}} \\
& \mathrm{n}=96,04 \approx 97 \text { atau dibulatkan } 100 .
\end{aligned}
$$

Maka sampel penelitian adalah 100 orang yang pernah menggunakan jasa PT. Pos Indonesia. Namun peneliti menambahkan 50 orang responden untuk mendapat hasil yang lebih reliabel. Teknik Pengolahan data yang digunakan dalam penelitian ini adalah Importance Performance Analysis (IPA). Importance Performance Analysis adalah metode untuk mengetahui seberapa besar pelanggan merasa puas terhadap kinerja perusahaan, dan seberapa besar pihak penyedia jasa memahami apa yang diinginkan pelanggan terhadap jasa yang mereka berikan.

\section{HASIL DAN PEMBAHASAN}

Didapat 2 atribut yang ada didalam kuadran A yang merupakan prioritas utama perbaikan yaitu Karyawan pos memberikan solusi apabila terjadi permasalahan kiriman dengan nilai kinerja 3.720, harapan 4.247 dan gap sebesar -0.527 dan Pos bertanggung jawab terhadap keamanan dalam pengiriman barang yang diterima dengan nilai kinerja 3.847, harapan 4.360 dan gap sebesar -0.513 . Adapun hasil pengoladan data menggunakan aplikasi SPSS 23.0 pembagian setiap atribut pada setiap kuadran ditampilkan pada gambar 1 berikut ini:

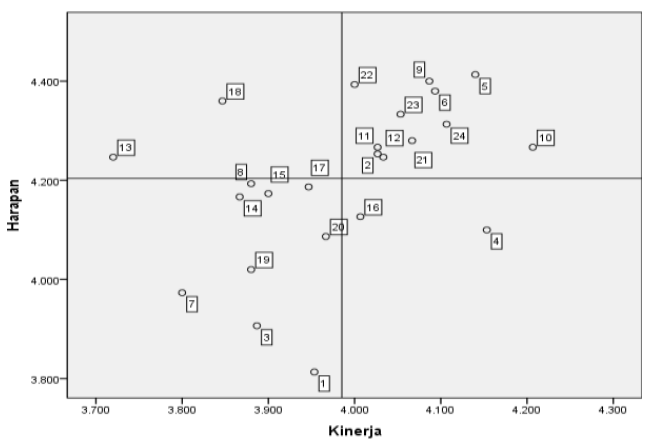

Gambar 1 Hasil Diagram Kartesius Sumber: Pengolahan Data, 2019 
Setelah dilakukan perhitungan menggunakan diagram kartesius didapat hasil atribut yang perlu untuk dilakukan perbaikan, dimana atribut tersebut dinilai tidak memuaskan para pelanggan PT. Pos Indonesia. Atribut yang harus diperbaiki pada kuadran A adalah:

\section{Tabel 2 Hasil Perhitungan Kartesius pada Kuadran A}

\begin{tabular}{|c|l|c|}
\hline No & \multicolumn{1}{|c|}{ Pernyataan } & Kuadran \\
\hline 1 & $\begin{array}{l}\text { Karyawan pos memberikan solusi } \\
\text { apabila terjadi permasalahan } \\
\text { kiriman }\end{array}$ & A \\
\hline 2 & $\begin{array}{l}\text { Pos bertanggung jawab terhadap } \\
\text { keamanan dalam pengiriman } \\
\text { barang yang diterima }\end{array}$ & A \\
\hline
\end{tabular}

Sumber: Pengolahan Data, 2019

Untuk atribut-atribut yang harus dipertahanan oleh pihak perusahaan setelah dilakukannya perhitungan menggunakan diagram kartesius adalah atribut atribut yang berada pada kuadran B, karena pada atribut yang berada pada kuadran B dianggap pelanggan sudah dapat memenuhi apa yang mereka inginkan. Adapun atribut yang harus dipertahankan adalah :

Tabel 3 Hasil Perhitungan Kartesius pada Kuadran B

\begin{tabular}{|c|l|c|}
\hline No & \multicolumn{1}{|c|}{ Pernyataan } & Kuadran \\
\hline 1 & $\begin{array}{l}\text { Kebersihan ruang tunggu dan } \\
\text { toilet terjaga }\end{array}$ & B \\
\hline 2 & $\begin{array}{l}\text { Kantor pos memberikan } \\
\text { kejelasan tentang biaya } \\
\text { pengiriman }\end{array}$ & B \\
\hline 3 & $\begin{array}{l}\text { Kantor pos memberikan } \\
\text { pelayanan yang cepat }\end{array}$ & B \\
\hline 4 & $\begin{array}{l}\text { Proses pengiriman yang } \\
\text { dilakukas POS menjaga barang } \\
\text { tetap sama atau tidak rusak } \\
\text { sampai tujuan }\end{array}$ & $\begin{array}{l}\text { Kurir kiriman memakai } \\
\text { attribute pos dan bersikap sopan } \\
\text { pada saat penyerahan paket }\end{array}$ \\
\hline 6 & $\begin{array}{l}\text { Customer Service kantor pos } \\
\text { peduli terhadap konsumen }\end{array}$ & B \\
\hline 7 & $\begin{array}{l}\text { Penyampaian informasi dari } \\
\text { karyawan pos dengan mudah } \\
\text { dapat dimengerti oleh anda }\end{array}$ & B \\
\hline 8 & $\begin{array}{l}\text { Karyawan pos berusaha } \\
\text { menciptakan hubungan yang } \\
\text { baik dengan pelanggan }\end{array}$ & $\begin{array}{l}\text { Karyawan menciptakan } \\
\text { komunikasi yang friendly }\end{array}$ \\
\hline
\end{tabular}

\begin{tabular}{|c|c|c|}
\hline & $\begin{array}{l}\text { sopan dan baik kepada } \\
\text { pelanggan }\end{array}$ & \\
\hline 10 & $\begin{array}{ll}\text { Karyawan } & \text { berusaha } \\
\text { menenangkan dan memberi } \\
\text { solusi apabila terjadi } \\
\text { permasalahan }\end{array}$ & B \\
\hline 11 & $\begin{array}{l}\text { Karyawan pos mendengarkan } \\
\text { pelanggan }\end{array}$ & B \\
\hline
\end{tabular}

Sumber: Pengolahan Data, 2019

Atribut yang memiliki penilaian yang rendah karena atribut-atribut ini kurang dianggap penting oleh pelanggan dan perusahaan juga tidak memberikan pelayanan atau perhatian khusus, atribut ini dianggap tidak memberikan dampak yang besar bagi perusahaan. Adapun atributatribut yang berada pada kuadran $\mathrm{C}$ adalah sebagai berikut:

Tabel 4 Hasil Perhitungan Kartesius pada Kuadran C

\begin{tabular}{|c|c|c|}
\hline No & Pernyataan & Kuadran \\
\hline 1 & $\begin{array}{l}\text { Penampilan atau desain tempat } \\
\text { yang dimiliki perusahaan PT. } \\
\text { Pos Indonesia Bandung sudah } \\
\text { memadai }\end{array}$ & $\mathbf{C}$ \\
\hline 2 & Tempat parkir kantor pos luas & $\mathbf{C}$ \\
\hline 3 & $\begin{array}{lll}\text { Biaya pengiriman } & \text { yang } \\
\text { diberikan oleh kantor } & \text { POS } \\
\text { relative murah } & & \\
\end{array}$ & $\mathbf{C}$ \\
\hline 4 & $\begin{array}{l}\text { Proses pengiriman paket yang } \\
\text { dilakukas POS cepat, tepat } \\
\text { waktu dan tidak salah alamat }\end{array}$ & $\mathbf{C}$ \\
\hline 5 & $\begin{array}{l}\text { Kemudahan dalam } \\
\text { menghubungi Customer Service } \\
\text { Pos }\end{array}$ & $\mathbf{C}$ \\
\hline 6 & $\begin{array}{l}\text { Customer service cepat dalam } \\
\text { menanggapi keluhan saya }\end{array}$ & $\mathbf{C}$ \\
\hline 7 & $\begin{array}{l}\text { Karyawan dapat merespon } \\
\text { dengan baik apa yang menjadi } \\
\text { keluhan saya }\end{array}$ & $\mathbf{C}$ \\
\hline 8 & $\begin{array}{lll}\text { Tersedianya } & \text { fasilitas } & \text { P3K } \\
\text { (Pertolongan } & \text { Pertama } & \text { Pada } \\
\text { Kecelakaan) } & & \\
\end{array}$ & $\mathbf{C}$ \\
\hline 9 & $\begin{array}{l}\text { Tersedianya peralatan pemadam } \\
\text { kebakaran }\end{array}$ & $\mathbf{C}$ \\
\hline
\end{tabular}

Untuk atribut yang ada pada kuadran D adalah atribut yang tidak dianggap penting bagi pelanggan, namun pihak perusahaan memberikan pelayanan yang berlebihan sehingga atribut ini dianggap berlebihan. Namun tidak menutup kemungkinan atribut ini juga akan mendapat 
perhatian yang lebih dari konsumen PT. Pos Indonesia. Adapun atribut yang berada pada kuadran D adalan sebagai berikut:

\section{Tabel 5 Hasil Perhitungan Kartesius pada Kuadran D}

\begin{tabular}{|c|l|c|}
\hline No & \multicolumn{1}{|c|}{ Pernyataan } & Kuadran \\
\hline 1 & $\begin{array}{l}\text { Karyawan pos menjaga kerapihan } \\
\text { dan penampilan }\end{array}$ & D \\
\hline 2 & $\begin{array}{l}\text { Karyawan mempunyai pengetahuan } \\
\text { untuk menjawab pertanyaan saya }\end{array}$ & D \\
\hline \multicolumn{2}{|c|}{ Sumber: Pengolahan Data, 2019 } \\
\hline
\end{tabular}

Sumber: Pengolahan Data, 2019

\section{KESIMPULAN}

Berdasarkan pengolahan data kualitas pelayanan PT. Pos Indonesia dengan dimensi tangible, reliability, responsiveness, assurance, emphaty menggunakan metode Importance Performance Analysis (IPA), diperoleh kesimpulan sebagai berikut:

1. Tingkat kepuasan pelanggan terhadap bukti fisik (tangible), kehandalan (reliability), daya tanggap (responsiveness), jaminan (assurance), empati (empathy) memiliki rata-rata tingkat kepuasan 0.948 yang berarti masih dibawah nilai harapan pelanggan yaitu 1.

2. Atribut yang menjadi prioritas utama dalam meningkatkan kualitas pelayanan adalah atribut yang masuk kedalam kuadran A berdasarkan pendekatan menggunakan metode IPA, atribut yang masuk kedalam kuadran ini yaitu : karyawan pos memberikan solusi apabila terjadi permasalahan pada kiriman dengan nilai kinerja 3.720 dan harapan 4.247 dengan gap sebesar -0.527 dan pos bertanggung jawab terhadap keamanan dalam pengiriman barang yang diterima dengan nilai kinerja 3.847 dan harapan 4.360 dengan gap sebesar 0.513

Tabel 6 Atribut Kuadran A

\begin{tabular}{|c|l|}
\hline Atribut & \multicolumn{1}{|c|}{ Pernyataan } \\
\hline 13 & $\begin{array}{l}\text { Karyawan pos memberikan solusi } \\
\text { apabila terjadi permasalahan kiriman }\end{array}$ \\
\hline 18 & $\begin{array}{l}\text { Pos bertanggung jawab terhadap } \\
\text { keamanan dalam pengiriman barang } \\
\text { yang diterima }\end{array}$ \\
\hline
\end{tabular}

Sumber: Pengolahan Data, 2019

Adapun beberapa hal yang sebaiknya perlu dilakukan guna melakukan perbaikan atau penyesuaian terhadap beberapa hal yang menjadi prioritas utama adalah: 13. Memberikan pengarahan kepada para karyawan mengenai pentingnya berinisiatif dalam melayani pelanggan yang membutuhkan bantuan, dapat juga dilakukan penambahan papan informasi untuk dapat mengurangi frekuensi timbulnya pertanyaan dari para pelanggan.

18. Kepercayaan adalah segalanya dalam bisnis jasa, informasikan pada pelanggan yang ingin mengirimkan barang bahwa pos bertanggung jawab atas keamanan dalam pengiriman barang yang diterima selama barang tersebut tidak melanggar ketentuan pengiriman salah satunya dengan cara membuat stand banner pada kantor pos yang berisi tahapan pengiriman barang dengan menuliskan $100 \%$ barang aman sampai tujuan.

\section{REFERENSI}

[1] Andri, Wili. 2007. Analisis Pengaruh Kualitas Pelayanan Terhadap Kepuasan Pelanggan. Skripsi. Yogyakarta: Universitas Sanata Dharma

[2] Candra, Ardian. 2010. Analisis Kepuasan Pelanggan Terhadap Kualitas Pelayanan Servis Bengkel PT. Bengawan Abadi Motor. Tugas Akhir. Surakarta: Universitas Sebelas Maret

[3] Nugraha, Yandi. 2012. Pengaruh Complaint Handling dengan Pendekatan Mekanistik Terhadap Customer Justice. Depok: Skripsi. Universitas Indonesia

[4] Titissari, Ayu. 2017. Pengaruh Kualitas Pelayanan dan Kualitas Produk terhadap Kepuasan Pelanggan PT. Pos Indonesia (Persero) Kediri. Skripsi. Yogyakarta: Universitas Negeri Yogyakarta

[5] Setyanto, Anggoro Danang. 2010. Pengaruh Kualitas Pelayanan Terhadap Loyalitas Nasabah dengan Kepuasan dan Komplain. Skripsi. Surakarta: Universitas Sebelas Maret

[6] Wardani, Tri Ulfa. 2017. Pengaruh Kualitas Pelayanan Terhadap Kepuasan Konsumen Pada Bisnis Jasa Transportasi Gojek. Sumatera Utara: Universitas Islam Negeri Sumatera Utara Medan

[7] Sitanggang, Abnertus Christoper. 2017. Pengaruh Penanganan Keluhan Pada Kepuasan Konsumen di Hotel Grand Praba Bandara Lampung. Skripsi. Bandar Lampung: Universitas Lampung

[8] Maudy, Inge. 2013. Analisis Penanganan Keluhan Terhadap Kepuasan Pelanggan PT. XL Axiata TBK di DKI Jakarta. Skripsi. Jakarta: Universital Telkom 